\title{
Location, location, location: does place provide the opportunity for differentiation for universities?
}

\author{
Emma Winter and Helen Thompson-Whiteside \\ University of Portsmouth
}

\begin{abstract}
The fiercely competitive HE market has led HEIs to invest significant resources in building a distinct identity. An HEI's location forms an inherent part of its identity and the uniqueness of location offers an opportunity to differentiate. However there has been limited examination of how location is used by HEIs and little consideration of how location can provide an effective means of differentiation. Through the lens of place marketing, this exploratory paper provides insight into the way HEIs portray location and discusses whether location can offer a source of differentiation.

Using a content analysis of prospectuses and interviews with marketing decision makers, this paper contributes a deeper understanding of the way in which a place brand is constructed by a stakeholder. The study reveals that HEIs portray a location to simultaneously excite and reassure the student which ultimately leads to the commodification of location. As such, differentiation is not possible.
\end{abstract}

Keywords: Location; Higher Education marketing; university; prospectus; place branding; content analysis

\section{Introduction}

Today's Higher Education (HE) environment is widely acknowledged as being highly competitive. The global rise in both student numbers and HE providers means that institutions need to work hard to differentiate themselves to attract students both nationally and internationally. As a result, many institutions are investing heavily in building a brand or identity in a bid to create a distinctive offering setting them apart from the competition. The benefits of branding Higher Education Institutions (HEIs) continue to be debated (Chapleo, 2015; Chapleo, 2010) but it is agreed that location is an inherent part of an institution's brand (Bennett \& Ali-Choudhury, 2009; Chapleo, 2010) and its innate ‘uniqueness' can offer a route to building a distinct identity. Location is known 
to be a determinant of student choice (Angulo, Pergelova, \& Rialp, 2010; Veloutsou, Lewis, \& Paton, 2004) and can provide an additional means for students to differentiate between HEIs with similar course offerings (Rutter, Lettice, \& Nadeau, 2016). It is therefore logical for HEIs to use location within their marketing materials. Yet to date, little investigation has been done to explore the way in which location is used or how it is portrayed. This research therefore aims to bridge this gap developing our understanding of the contribution location makes to the marketing of an HEI and whether it can provide an effective means of differentiation.

Whilst HEIs have enthusiastically adopted online and social media platforms to communicate with prospective students, the prospectus continues to be an important communication tool in helping students and their families to make choices between HEIs (Rutter et al., 2016; Shaw, 2013). One role of the prospectus is to reduce perceived risk (Johnson, 2001) and to act as a means of reassurance. Indeed, it is acknowledged within the HE marketing literature that institutions are under pressure to emphasise their similarities with competitors to show that they meet expected standards and can be considered legitimate (Rutter et al., 2016). This presents a potential challenge for differentiation. Here we explore how location is being used within the prospectus to meet the potentially conflicting objectives of appearing both similar yet different, and consider whether differentiation based on location is possible.

In providing location information, HEIs are engaging in place marketing and therefore this study uses place marketing theory as a frame for exploring the role of location for the HEI. In common with marketers of consumer products and services, the marketers of place are also seeking to establish differentiation and preference for a given location in the minds of the audience (Hanna \& Rowley, 2013). In the place branding literature, place brands are discussed as place offers (Warnaby \& Medway, 2013) which are constructed and assembled by a complex range of stakeholders (Aitken \& Campelo, 2011) from a range of tangible and intangible attributes (Cresswell \& Hoskins, 2008; Hanna $\&$ Rowley, 2013). The key contribution of this paper is to use the lens of place marketing to develop our understanding of the marketing of location, to inform our exploration of how HEIs are portraying location within the prospectus. From this, we will have a much clearer understanding of whether location can indeed become a source of differentiation as has been suggested.

\section{Marketing place}

Place marketing is a rapidly expanding field attracting increasing attention from academics and practitioners alike. The number of place branding studies continues to grow (Lucarelli \& Berg, 2011) and cities, towns and regions are increasingly turning to place branding consultancies to develop and articulate a distinct identity. Just as HEIs are seeking ways to compete in a crowded market, places 
are also responding to the threat of substitution (Hanna \& Rowley, 2013) increased competition for investment, employment, visitors and spend by seeking to differentiate themselves (Hanna \& Rowley, 2011) and create a sense of attachment with potential audiences (Colomb \& Kalandides, 2010). They may also be seeking to build on positive associations or indeed counter negative perceptions.

Indeed, there is consensus in the literature that the attributes of cities and towns, whether based on their heritage, their culture or natural resources, can be used to create distinctive brand images for geographic locations which allow them to be differentiated from each other (Kemp, Childers, \& Williams, 2012). Place marketers are therefore involved in marketing a product that relates to a specific geographical location (Warnaby \& Medway, 2013) with a name that has usually emerged from this geography and its history (Medway \& Warnaby, 2014).

Place marketing, led by practitioners, has been dominated by a view that a place can be seen as a product, as something fixed and static (Kavaratzis \& Hatch, 2013). The job of the place marketer then is to define and distil the nature of that place in order to inform a place identity. This can then be communicated via centralised messages and agreed images to target audiences in order to create a desired brand image (Kavaratzis \& Hatch, 2013) and generate expectations prior to consumption (Kemp et al., 2012). Critics of this approach argue that place branding is too often thought of as something that is ‘done to a place' by practitioners (Braun, Kavaratsis, \& Zenker, 2013) and excludes other stakeholders (Aitken \& Campelo, 2011). Communicating one dominant view of a place can also suppress the very distinctiveness that could have provided the basis for differentiation (Medway et al., 2015). Eisenschitz (2010, p. 27) argues that as places increasingly adopt formulaic marketing strategies 'then no city will have a unique selling point' leading to the commodification of place (Warnaby \& Medway, 2013).

By contrast, others argue for the complexity and ambiguity of a place product. The many target audiences for a place can be heterogeneous (Kemp et al. 2012), its many attributes can be difficult to define and control (Hanna \& Rowley, 2015; Kavaratzis \& Hatch, 2013) and unlike a corporate brand, ownership is not easily claimed (Fan, 2006) although it often falls to local government or a Destination Management Organisation (DMO). In any case, there is a consensus that the place marketer will draw from the raw material of identity, from both its physical attributes what might be thought of as the tangible form of the city and from a less concrete, intangible realm of meaning (Cresswell \& Hoskins, 2008; Hanna \& Rowley, 2013). Therkelsen, Halkier and Jensen (2010) sum up this idea when they describe the notion of the 'city of stones' and the 'city of words'. A city of stones describes a material place defined by the infrastructure and the built environment of a location whereas the city of words is a place that is built through meaning, stories and narratives. These two realms are mutually supportive of each other (Warnaby \& Medway, 2013) and can be assembled or curated by place marketers to create a place offer. Narratives might be used to create an 
'imaginary geography' to which others are invited but there is an increasing recognition that narratives can come from a variety of sources not just place marketers. As a range of stakeholders have direct and indirect experience of a location, they will construct their own narratives and become not just consumers but also producers of place (Lichrou, O'Malley, \& Patterson, 2014). Location or place is then seen as something that is produced and reproduced by human actors; as a process rather than a static product (Kalandides, 2011). Through this lens, place is not a fixed product but might more usefully be thought of as a social construct, as lived and assembled by a range of stakeholders. The understanding of place marketing is therefore moving from a view of place communications which are imposed from a central point to a more flexible and inclusive notion of a place as curated and co-created by its many stakeholders (Medway et al., 2015). Although the portrayal of location must always be substantiated in terms of what is on offer, the representation of place will depend not just on the target audience being addressed (Hanna \& Rowley, 2015) but on who is telling the story. As Warnaby and Medway (2013, p. 350) comment, 'place lies firmly in the eye of the beholder'.

In addition, the notion of place is not always clearly aligned to geographical or administrative boundaries (Warnaby \& Medway, 2010). Warnaby (2009) coined the term 'place fuzziness' to describe the often overlapping and fluid boundaries of place. Furthermore, as people and goods are increasingly mobile, the boundaries of place are not only considered fluid but permeable. The literature increasingly recognises that a place brand can rarely stand alone and is usually understood relative to other places (Kalandides, 2011). The mobility of people and capital across place boundaries together with political and economic initiatives can sometimes give rise to new districts, zones or regions and toponymic (place name) changes (Medway \& Warnaby, 2014). This is true when there is either a desire to build on positive place associations or alternatively, move away from negative associations. Places may be connected however, not just to other place brands but also corporate and people brands in a place brand ecosystem (Medway et al., 2015). Hanna and Rowley (2015) similarly describe a web of other brands associated with a place which all help shape the perception and experience of a location but are outside the control of any one party. Place then might be better understood as something that is co-created by a number of parties.

Brand personality is also discussed in the place branding literature as a potential competitive advantage. It can play a key role in decision-making and the consumer's ultimate choice of brand (Kaplan, Yurt, Gunuri, \& Kurtulus, 2010). This is particularly helpful when consumers perceive a match between their own personality and that of the place brand allowing them to make self-brand connections. Of particular interest here is the understanding that potential consumers may choose to connect with those place brands that best enable them to create and express their own desired identity (Kemp et al., 2012). In this way, the identity of place and self-identity might both be created. Strong 
self-brand connections would not just attract an audience but create strong brand advocates for the future.

Places are seeking to respond to increased competition and avoid substitution by adopting marketing and branding strategies. Early adoption of these strategies appeared to be restricted to the imposition of one centralised view of place however in recent years, place branding literature has argued for a paradigm shift. Rather than a process of imposing one fixed view of place with a dominant narrative, our understanding of place is now seen as a more fluid and continuous process of curation undertaken by many stakeholders. Implicit in this shift is a recognition that by working with a range of stakeholders, place can be dynamic and co-created and there is also recognition that subbrands associated with place may offer the opportunity to further build brand equity. HEIs are complex organisations which have adopted marketing and branding strategies to differentiate themselves in a competitive marketplace. Whilst location is an inherent part of the HEI identity, there is a gap in our understanding of how or why location is being used. Building upon the theory of place marketing, our research intends to bridge this gap by exploring how HEIs are portraying their location within their prospectus and whether location provides a source of differentiation.

\section{Method}

As an exploratory piece of work, our study is qualitative in nature. The aim is to explore how location is used in the prospectus and the decision making behind that. According to Atkinson and Coffey (2011) this necessitates using the prospectus as both a 'resource' and a 'topic' - focusing on what is in the document and how that content came into being. Therefore the research was undertaken in two parts - a content analysis of prospectuses, followed by semi structured interviews with HEI marketing decision makers.

The content analysis was undertaken using a convenience sample of 105 undergraduate prospectuses. At the time of writing, there are 143 undergraduate, non-specialist Higher Education providers in the UK (HESA) and therefore the sample size is statistically representative to provide 95\% confidence with a 5\% margin of error (Krejcie \& Morgan, 1970).

The UK HEI market can be sub-divided based on age of institution (classified as ancient, civic, plate glass, new and recent) and whether or not the institution belongs to the Russell Group, a group of 24 'research-intensive, world-class universities’ (The Russell Group, 2017). The prospectuses were chosen to represent a broad spread of HEIs in terms of age of institution, Russell Group or non Russell Group and geographical location within the UK. As the objective of the content analysis was to ascertain how location was being presented, any writing and text referring to a description or discussion of the location and the environment outside of the HEI's control was 
reviewed and coded to generate a list of 'phrases, concepts, ideas and themes' contained in the text (Atkinson \& Coffey, 2011). This included specific location sections, eg 'About the City', as well as more general text within the prospectus that made reference to the location, such as reflections from current students and alumni or a general introduction from the Vice Chancellor. The content analysis looked only at text and did not review any use of images within the prospectus.

Following the content analysis, semi structured interviews were undertaken with $15 \mathrm{HEI}$ marketing decision makers. The sample was self selected from members of the CASE (Council for Advancement and Support of Education) UK Universities Marketing Forum - 'a voluntary association of university directors of UK marketing and recruitment from the HE sector' (UK Universities Marketing Forum, 2017)

In order to protect the participant's anonymity we have intentionally not provided a breakdown of their job titles or HEIs. However the sample included copywriters, recruitment managers and marketing directors from across the age range of institutions and from both Russell Group and non Russell Group universities. An overview of participants can be seen in Table 1 .

\begin{tabular}{|l|l|l|}
\hline Participant Number & Age of HEI & Russell/Non Russell Group \\
\hline Participant 1 & Ancient & Russell Group \\
\hline Participant 2 & Ancient & Russell Group \\
\hline Participant 3 & Civic & Russell Group \\
\hline Participant 4 & Civic & Non Russell Group \\
\hline Participant 5 & Civic & Non Russell Group \\
\hline Participant 6 & Civic & Non Russell Group \\
\hline Participant 7 & Plate Glass (1960s) & Russell Group \\
\hline Participant 8 & Plate Glass & Non Russell Group \\
\hline Participant 9 & Plate Glass & Non Russell Group \\
\hline Participant 10 & Plate Glass & Non Russell Group \\
\hline Participant 11 & New (post 1992) & Non Russell Group \\
\hline Participant 12 & New & Non Russell Group \\
\hline Participant 13 & New & Non Russell Group \\
\hline Participant 14 & New & Non Russell Group \\
\hline Participant 15 & Recent (post 2001) & Non Russell Group \\
\hline
\end{tabular}

Table 1 - list of participants 
The list of themes and concepts from the content analysis was shared with the participants and formed the basis of the interviews. The questions asked were broad, allowing the participants to have a general discussion with the researchers outlining how they choose to portray location within the prospectus and the decision making behind this, as well as the role in which location plays in building the HEI identity. The interviews lasted up to 70 minutes and were all audio recorded and transcribed.

We undertook a thematic analysis of the verbatim transcriptions at a semantic level, where themes were identified from the responses that participants provided rather than looking for any underlying assumptions (Braun \& Clarke, 2006). In the first instance, initial codes were generated (Miles \& Huberman, 1994) by each researcher and then broader themes were identified by looking at data gathered across all interviews (Braun \& Clarke, 2006). These themes were then reviewed and refined by both researchers to ensure agreement was reached.

Findings will be discussed in the following section but it is important to emphasise that the anonymity required by participants means that we have not attributed direct quotes to institutions.

\section{Themes identified by the prospectus content analysis}

The purpose of the content analysis was to explore the way in which location was being presented in the prospectus and so the key themes that were identified concern: 1) what information was being presented; and 2) how that information was being presented.

\section{Outlining the location's facilities}

The content analysis highlighted the fact that the majority of location information presented drew attention to the physical facilities on offer. Table 2 shows the facilities and features that are most likely to be outlined in prospectuses.

\begin{tabular}{|l|l|l|}
\hline Facility/Feature & Example & $\begin{array}{l}\text { Percentage of } \\
\text { prospectuses } \\
\text { mentioning this } \\
\text { feature }\end{array}$ \\
\hline Arts and culture & Theatre, galleries, & $95 \%$ \\
\hline Natural environment & $\begin{array}{l}\text { Urban green space, coastline, } \\
\text { countryside }\end{array}$ & $92 \%$ \\
\hline Nightlife & Pubs, clubs & $90 \%$ \\
\hline Architecture & Modern, historic & $89 \%$ \\
\hline
\end{tabular}




\begin{tabular}{|l|l|l|}
\hline Shopping & $\begin{array}{l}\text { High street shopping, independent } \\
\text { shops }\end{array}$ & $88 \%$ \\
\hline Eating and drinking & Restaurants, cafes, coffee shops & $87 \%$ \\
\hline Music & Live bands, DJs, rock concerts & $87 \%$ \\
\hline Light entertainment & Cinema, comedy clubs & $82 \%$ \\
\hline Sporting opportunities & $\begin{array}{l}\text { Participating or spectating in non- } \\
\text { university organised sport }\end{array}$ & $79 \%$ \\
\hline Proximity to other locations & $\begin{array}{l}\text { Explicit mention of time or distance } \\
\text { from a major UK city }\end{array}$ & $73 \%$ \\
\hline Transport links & Motorways, train stations, airports & $63 \%$ \\
\hline Location specific fact & $\begin{array}{l}\text { Explicit mention of something the } \\
\text { location is famous or known for (eg } \\
\text { Birthplace of Nelson) or something } \\
\text { that is based in the location (eg home } \\
\text { of the world's oldest pub) }\end{array}$ & $46 \%$ \\
\hline Safety/low crime & $\begin{array}{l}\text { Explicit mention of being a safe } \\
\text { location or having low crime }\end{array}$ & $\begin{array}{l}\text { Explicit mention of cost effectiveness } \\
\text { eg, low cost, cheap }\end{array}$ \\
\hline Cost effectiveness & $24 \%$ \\
\hline
\end{tabular}

Table 2 - facilities and features of a location most likely to be outlined within the prospectus

\section{Describing the location's facilities}

Rather than present readers with a list of facilities on offer, the location's amenities tended to be presented in a very descriptive way using words and phrases which were overwhelmingly looking to generate an emotional response; particularly to arouse or excite.

It's a vibrant, friendly city that's really geared up towards student life - with lively music and arts scenes, enticing places to eat and drink, a fantastic range of shops.....

The most frequently used arousal words were vibrant, thriving and lively.

\section{The extent of location}

In line with the concept of place fuzziness (Warnaby, 2009), the final theme identified in the content analysis was that the location commentary was not confined to the immediate geographical proximity in which the HEI is situated. In a number of instances, the location discussed extended beyond the immediate vicinity and reflected upon the HEI's wider county or region of the UK and in some 
instances, neighbouring towns or cities were included within the location presented. These fluid location boundaries enable the prospectus to offer up an extended selection of facilities. For example

Just 12 miles north of [location A], [location B] offers a wide variety of pubs and restaurants, museums, theatres and galleries...

Having undertaken the content analysis to explore what was being said about location, the three key themes were used as a starting point for the interviews with marketing decision makers to explore the decision making behind the presentation of location.

\section{Themes identified within the interviews}

Having undertaken the content analysis to ascertain how location is being presented, the interviews with marketing decision makers enabled us to explore the decision making behind presenting that information. For marketing decision makers, the purpose of including location information within the prospectus is multi faceted.

\section{Contextualising the Place}

Many UK students are surprisingly geographically unaware (Winter \& Chapleo, 2017). Taken in conjunction with the increased recruitment in international students, this means that from the marketing decision maker's point of view, one of the key functions of including location information within the prospectus is to convey the HEI's geographical location to those unfamiliar with the area or region. There are some parallels that can be drawn here with (Kalandides, 2011) and the need to understand place relative to other places.

Unsurprisingly, use of a city name in the title of the HEI was felt to be overwhelmingly positive in conveying the geographical location, and there was some discussion of HEIs that had changed their name to incorporate a city within the title in line with the toponymic (place name) changes outlined by Medway and Warnaby (2014). Additionally, the advantages of being an HEI including the name of a city with a successful football team were not overlooked:

If the city is in the premier league ... it does give you international coverage on a huge scale because the name of the city is being marketed for you worldwide...so its constantly reinforcing the message of [location] and the fact that its vibrant and it's got a great team ...

Some participants talked of raising the profile of the area beyond the immediate vicinity and how it is important to talk about the wider region, particularly for the international market. This is more often the case with HEIs situated in distinctive areas of the UK, such as Wales and Scotland. 
Conversely, it was felt that where the HEI name includes a region or county name in their title, this does little to aid prospective students and parents in understanding the geographical location:

We were previously called University of $X X$... well we dispensed with that name as nobody actually knows where $X X$ [UK region] is.

For smaller cities or towns and HEIs not including a city name, there is also a desire to raise the profile and highlight the existence of the location, or as one participant put it, to 'put the city on the map'. Linking strongly to the need to understand place relative to other places (Kalandides, 2011), one way in which this is achieved is to talk about proximity to major cities. London is the usual geographical marker, '90 minutes from London on the train', but sometimes other major cities are more appropriate, e.g. Glasgow or Manchester. Additionally, recognition of a location can be achieved by citing something the city or town is famous for, such as being home to 'Wales' tallest building' or 'birthplace of Charles Dickens'.

\section{Challenging and trading on perceptions}

Whilst providing some context of location is important, in line with Medway and Warnaby (2014), there is often a greater desire to 'shift perceptions' and this was discussed in the majority of interviews. As well as being geographically unaware, many prospective students’ perceptions of cities are almost entirely formed by others' views or conventional wisdom... 'my mum said it was the second roughest city in the UK' (Winter \& Chapleo, 2017, p. 192). Although it is not always the case, these perceptions can be based on negative and outdated information and so the prospectus becomes a key vehicle for marketing directors to shift perceptions and present a more up-to-date view of a town or city.

There was still a sense that [location] was too far away, it was remote and nothing really happened there, it was like the criminal underbelly.... so there is a huge amount of perception shifting that we've had to do. If you ask local people about [location] they will understand that it just isn't that kind of place, but outside and further afield there's a sense that it's not very nice.

Participants explained how reverse messaging can be achieved through 'harnessing core messages' about their location and in particular 'buying into the halo effect' created by large city hosted events, such as The Commonwealth Games or the Americas Cup or a music festival, but participants were also keen to stress it can be achieved by challenging perceptions, highlighting the 'sorts of things you might not expect to find'. 
But not all perceptions of location are negative. Some perceptions, whilst they may be clichéd, are positive and marketing decision makers are keen to 'make the most of the obvious points' and to use this to their advantage:

I guess we are kind of trading on everyone's perceptions of what it [county] means So you've got lovely shots of the Highlands, bagpipe playing, hairy cows, the lovely islands with their coloured houses......

\section{Deciding on the location content}

\section{Something for everyone}

None of the marketing decision makers were surprised by the fact that considering all of the copy on location, it is the location's facilities that are conveyed the most prominently. Although all participants were adamant that there wasn't a tick list of elements to include, as highlighted by Rutter et al. (2016), the need for HEIs in the same market space to meet a minimum set of assumed standards was clear. The similarity of content between prospectuses was striking and the findings identified a consistent trend of show casing the many physical attributes of the town or city with the apparent desire to highlight that their location can offer something for everyone; or as one participant said 'whatever you like, we've got it'.

Whilst only one participant worked for an HEI that formed part of a city Destination Management Organisation, most participants talked of informal links with their towns/cities and relationships that had been created between individuals within the HEI marketing team and their civic counterparts, recognising that the place brand consists of sub-brands such as the HEI which can also shape perceptions of place (Hanna \& Rowley, 2013). Whilst these relationships often facilitated some involvement with city brand managers on specific projects, all participants explained that the decisions behind what to include within the location information was very much down to the HEI itself, rather than any formal agreement or direction by city brand managers or local tourism officials.

All participants spoke very positively about their locations and conveyed a genuine passion for their towns and cities. The writing of the copy itself is generally done in house by the HEI marketing team who 'have the knowledge, expertise and practise' at putting good copy together. Acknowledging that the prime audience for the prospectus is the 18-24 year old, many participants explained how the copy is written by a young author whose style of writing can more readily appeal to the key audience. A small number of participants talked of third party involvement in putting together location content, such as Lonely Planet. This was driven by a desire for authenticity and objectivity. 
The decision on what should be included within the location content is generally decided by reviewing what has been written in the previous year and making necessary amendments to keep the copy 'up to date' and 'lively and interesting'. New content is included where appropriate, such as major city events or sports team news, and facts and figures from new third party reports are included - eg 'Britain's favourite city' or 'Most cost effective student city in UK' - further underpinning the desire for credibility.

None of the participants said copy was written with a particular type of student in mind, they were simply targeting 'young people' of the typical undergraduate age, and acknowledged that students were diverse in their tastes. Some participants reflected upon a growing desire to better understand their typical student to enable them to write more specifically for that audience, but had yet to take action. A few participants felt that their typical student was a 'bit edgier' or a 'bit quirkier' yet didn't feel that necessarily altered the way in which they presented location and therefore the opportunity to build on self-place brand concepts as described by Kemp et al. (2012) is not being taken. Participants were aware that the prospectus had a secondary audience - parents - who are a known influence when it comes to HEI choice and suggested that the desire to promote the arts and cultural scene in the prospectus was aimed perhaps more at parents than it was at prospective students.

With the growth in international student numbers and widening participation students, there is undoubtedly a need for many HEIs to be inclusive, and the wide variety of offerings outlined in the prospectus goes some way to representing this. However participants were keen to explain that the broad offering of location facilities outlined in the prospectus is also about 'giving a flavour of the place' to appeal to the diverse student mix they are trying to attract.

\section{Student generated content}

Whilst the HEI takes responsibility for writing and collating copy itself, the growing trend for student generated content was a strong theme or was under consideration and a number of HEIs are recognising that place narratives can come from other sources. Driven by both their experience of and attachment to place (Lichrou et al., 2014), HEIs are enabling current students or alumni to become not just consumers, but producers of place as they reflect upon their experiences of the location. Where students are not generating content themselves, they are still influencing the way in which location is presented and some participants talked of including aspects of the location that students have talked about on social media to steer the content and direction of the location information. In this way HEIs appear to be moving away from imposing a view of location to one of curating the views of stakeholders. 


\section{Nightlife and a social scene}

Whilst the nightlife and social scene are facilities outlined and presented in most prospectuses, all participants were in firm agreement that they deliberately aim to keep nightlife low key. Part of this stems from cultural sensitivities surrounding alcohol and there is also an awareness that overemphasis of this facet of location is unlikely to appeal to parents. However some description or outline of nightlife (including pubs, clubs and bars) appears in $90 \%$ of prospectuses. This anomaly may be because there is a quiet acknowledgement that some sort of nightlife is expected by many undergraduates which again, links to the ideas of conformity and legitimacy as discussed by Rutter et al. (2016). To omit nightlife from the prospectus all together would suggest that the HEI was unable to provide an equitable offering to competitors and therefore its legitimacy as a HEI is undermined.

All participants explained they are careful not to show any imagery of alcohol or nightclubs and so perhaps this is what leads them to conclude they are not highlighting it. It's an interesting dichotomy borne out by one participant:

We certainly don't want to be talking about nights out and drink etcetera and we're careful with our images

and who later commented that it was important to:

convey a fun-loving, infectious, friendly and energetic social scene

The content analysis showed that $58 \%$ of all uses of vibrant and $71 \%$ of all uses of lively were made in relation to 'nightlife'. Perhaps it is not discussed as much as other facilities offered within the location but nightlife is certainly portrayed to arouse excitement.

\section{Use of brand names}

The prospectus content analysis highlighted that the mention of specific brand names within the location is not uncommon. In line with the concept of the place brand web, there was a recognition that links to other brands will also shape perception (Hanna \& Rowley, 2015), and can enhance brand equity (Hanna \& Rowley, 2013). Participants were somewhat surprised by this although did explain that it had two benefits: firstly, it enables the size of the city to be conveyed:

If you have a Harvey Nics and an Apple [store] you are saying something about the size of the city

and secondly, it provides reassurance that students will find the familiar:

It is not an unreasonable expectation from the audience that they will have consumer brands available to them that they are used to 
Yet the decision on what brand names to mention was very much down to the individual copywriter and there was an acknowledgement that those decisions 'probably reflect the prejudices of staff rather than the preferences of students'

\section{Use of language}

The content analysis highlighted the frequent use of descriptive writing to create a 'city of words' (Therkelsen et al., 2010). For all but one participant, there was a strong desire to use the location information in the prospectus to 'convey a lifestyle'. Most participants explained that their HEIs had 'tone of voice' guidelines and that copy is written in language that is both understood by, and appeals to prospective students but will also sit comfortably with their parents. Prospectuses in general are written in a deliberate 'magazine style', using alumni success stories and student voices to create an authentic and friendly feel; the location elements are no exception. Interestingly, the one participant who did not concur with this, explained that the HEI had previously adopted this approach but were now moving towards content that was more 'matter of fact'. This could be seen as a step back towards the static view of place and a conscious decision not to encourage place attachment (Kemp et al., 2012).

\section{A sense of excitement yet familiarity}

There was a very strong belief amongst all participants that in coming to university, students seek the excitement of a new experience. Therefore it was a conscious decision from all participants to try to convey the sense of adventure in their outline of location. Building on this, the theme of seeking to convey a dynamic and positive location personality was strong and some participants explicitly talked of needing to build an emotional connection with the reader. This finding is consistent with the selfplace brand concept whereby consumers may choose to connect with those place brands that best enable them to create and express their own desired identity (Kemp et al., 2012). The extensive use of arousal words highlighted by the content analysis -vibrant, lively, buzzing, bustling - reinforces the desire for an emotional bond. Yet none of the participants said the choice of words used was intentional; it was more a desire to create good copy rather than a deliberate choice of specific words to elicit a certain reaction.

Whilst conveying excitement is important, participants acknowledged that also being able to offer a comforting and familiar environment is key for the many prospective students who are leaving home for the first time. 'Students need to feel as though they will fit in' and so communicating a sense of belonging is equally as important as generating excitement. Through outlining a range of facilities that are likely to have already been experienced in the prospective student's home town - cinema, coffee shops and shopping opportunities - and incorporating some familiar brand names - Odeon, Starbucks, H\&M - participants discussed how they aim to offer continuity and familiarity. 
It's all about building an emotional response and a sense of belonging so that when somebody comes to a decision, what we hope we've established in their mind... is that [HEI] just feels right ... I could get along here. What we're trying to do is convince people that we're a wise choice.... we're a sensible choice.

The explicit notion of the wise choice was mentioned by a few participants but was implied by more. This appears to further underline the need to meet a minimum set of standards in order to gain legitimacy in the ideas of the student audience as discussed by Rutter et al. (2016). Many participants spoke at length about choice of HEI being an emotional decision but some talked of there also needing to be a rational basis for that decision. Highlighting aspects of location such as transport links, safety or cost effectiveness in addition to extensive facilities was felt to go some way to achieving this.

\section{The impact of location on HEI identity and brand}

For a number of participants their HEIs were very much in a period of transition where there was an increasing focus on honing the identity and refining the brand of the institution. There was a clear feeling that the location does inform part of that identity, but this was to differing extents. Typically, it was suggested that the location is a 'distinctive proposition that informs our brand' but that this should be relative to the desire to portray the HEI as a centre of knowledge, expertise or academic excellence:

The brand identity for the university is distinct from the brand identity of the city but there is a complementarity in what we do

In most cases participants talked of creating synergies between the location and the HEI by assembling a place offer (Warnaby \& Medway, 2013), these marketers are taking positive attributes of the location and fitting these to the HEI identity. In many cases these positive attributes were centred on the environmental characteristics of the location such as being on the coast or being in a large city and drawing on material attributes. However in the case of one HEI with an obvious seaside location, the participant outlined a conscious desire from the HEI executives that the brand should not focus on location and instead should focus on much more 'substantial' attributes; a feeling that somehow the association of this particular location might be negative and detract from the expertise and knowledge within the institution.

Of course using the location to inform the HEI identity does pose some issues for multi campus HEIs, particularly when the other campuses are located in completely different parts of the UK or overseas. As one participant asked: 
How do you create that [location] feel when you are sitting in a campus in Dubai

or China or Malaysia?

This is, of course, a difficult question to answer although two participants talked of how it was important for HEI staff to 'embody the spirit of a location' and that this can help in reinforcing synergies between the location and HEI identity.

\section{Discussion and conclusions}

The core contribution of this research lies in drawing on the place marketing literature to explore how place is marketed to inform our understanding of how HEIs are portraying location within the prospectus and whether differentiation is possible. In order to draw a conclusion, it is important to consider these key findings:

\section{Location doesn't exist, it is in the eye of the beholder}

Current place branding literature suggests that location is not a fixed or stable product (Hanna \& Rowley, 2015; Kavaratzis \& Hatch, 2013) or indeed always clearly aligned to geographical boundaries. Instead, the concept of location is fluid and can mean different things to different stakeholders. HEIs have partly embraced this view although the approach appears to be haphazard. Marketing decision makers are happy to assemble their own place offer rather than rely on city brand managers or a Destination Management Organisation to direct them. However whilst there is a desire for location to be portrayed in a way that will both stimulate and comfort, there is a lack of clarity surrounding a more specific place offer. Without a clear and distinct approach in terms of how to present location, it becomes very difficult curate a meaningful offer or to use location as a basis for differentiation.

Embodying the spirit of place fuzziness (Warnaby, 2009), HEIs are happy to construct their location both from the immediate vicinity and beyond in their desire to offer both excitement and reassurance. Consistent with the view of Kalandides (2011), it would seem that a place can be understood in relation to others, so for example in the case of the campus university that might be situated in a small town, the nearby larger city is called upon to offer the familiar mix of shopping, entertainment and culture. The compact nature of the UK means that nowhere is particularly far from the coast or countryside; both of which can offer excitement in the form of dramatic landscape or perhaps adventurous sports. All our participants talked of their prospectus having a deliberate design to appeal to a very broad audience; if marketing decision makers feel their own immediate location is lacking in part of the offering, there is a conscious decision to borrow this feature from the wider 
environment. While the place branding literature suggests that place boundaries are permeable (Warnaby \& Medway, 2010) allowing for the flow of people and brands, marketing decision makers' rationale for widening the location is likely to stem from an understanding that students are willing and able to be mobile, along with a desire to be able to present a comprehensive list of tangible offerings. In doing this, HEIs are continuing to communicate a very generic view of location and are suppressing the distinctiveness that might have provided the basis for differentiation (Medway et al., 2015).

\section{Location should be more than a 'city of stones'}

Whether reflecting on the immediate vicinity or beyond, by concentrating on the physical features and attributes that the location has to offer, HEIs are presenting only a city of stones (Therkelsen et al., 2010) and are in danger of ignoring the social constructs and realm of meaning (Hanna \& Rowley, 2013) that can also shape the location (Kalandides, 2011) and define its essence.

In terms of the prospectus, marketing decision makers do not write with a specific target audience in mind. The main reason for this is the desire to target a very broad range of individuals. With the majority of their income drawn from undergraduate fees (Universities UK, 2016) UK HEIs are in direct competition with one another and are therefore understandably reticent to narrow their appeal and give their competitors an advantage. Prospective students make their choice from an evoked set. With the prospectus often being the only source of information used by prospective students (Winter \& Chapleo, 2017) and the importance of appearing legitimate (Rutter et al., 2016), HEIs must be able to show within the prospectus that their location is at least as good as the competition. Yet in common with place marketing, as increasingly formulaic marketing strategies are adopted which can lead to commodification, 'then no city', or in this case, an HEI, 'will have a unique selling point' (Eisenschitz, 2010, p.27). In other words, if everyone is presenting a comparable offering, then nobody is differentiating.

As well as deliberately targeting a broad range of individuals, marketing decision makers are not writing with a specific audience in mind because they are lacking understanding of who their typical student is. Although there is a move towards the use of contributions from students and alumni to create a more socially constructed version of location, without a clear avatar in mind crafting the 'city of words' (Therkelsen et al., 2010) also becomes increasingly difficult. Through a social construction of stories and narratives, a realm of meaning or the city of words is created in order to create a sense of place attachment and enhance self-brand fit in the minds of the potential students. Yet for a sense of attachment or belonging to really be felt, those personal accounts must have meaning to the reader and without a reader in mind, meaning is hard to infer. HEIs would benefit from considering the concept of a place brand ecosystem (Medway et al., 2015) or web (Hanna \& Rowley, 2015) to move 
towards constructing a more collaborative place offer. This could present prospective students with something more meaningful; a suggestion that the location can offer something specifically for them.

\section{Can location offer a means for differentiation?}

It would seem strange to think that this could not be the case in the UK where so many towns and cities offer unique architecture, rich civic culture and diverse populations. Through the prospectus, the HEI must demonstrate that it is a centre of knowledge and academic excellence which offers a positive teaching experience whilst being situated in a location that meets the minimum standards expected by students. The role of the prospectus is simply a means for HEIs to put themselves forward as legitimate contenders; put simply to 'put your best foot forward' and to encourage prospective students to take the next step in their decision making - a visit to the HEI . This formulaic approach leads to the commodification of location and therefore we conclude that the prospectus is not the place to use location as a source of differentiation.

It should be recognised that developing a distinct brand personality could help target audiences perceive a self-brand fit (Kemp et al., 2012). This perception of fit with the personality of the HEI's location could attract potential students and allow them to feel that in this place they can realise their own desired identities. In adopting a 'something for everyone' approach, HEIs may be reassuring students but they are not sufficiently differentiating or designing their location to appeal to distinct audiences. Without a clearer sense of an avatar or indeed a better sense of their own identity or personality, HEIs will not be able to further exploit this opportunity.

That is not to say that location per se cannot be used as a means of differentiation. Whilst the prospectus is not necessarily the correct medium for differentiation, the opportunities to differentiate through location still exist. This may be more easily exploited through other marketing media and further along in the decision making process, as prospective students gain confidence in their choices and seek to make stronger connections between themselves and the place brand.

\section{Implications for HE practice}

\section{Agree the location narrative}

To ensure a clearer focus, marketing decision makers should move towards agreeing a more specific location narrative. If the identity and contribution of the location from the viewpoint of the HEI can be agreed, then the HEI can better communicate to its students 'what our location means to you'. Although this may not alter the key intention within the prospectus to both excite and comfort, it would at least ensure that a more meaningful and authoritative portrayal of location can be presented. 


\section{Use imagery rather than words}

The prospectus is an important communication tool at the beginning of the decision making journey, helping students to narrow their choices. Therefore it is accepted that HEIs are unlikely to want to deliberately position their location offering to a specific type of student so early in the decision making timeline when their intention is just to 'give a flavour'. Imagery within the prospectus is already acknowledged as important and its continued use should be encouraged. The use of an image rather than words can infer many different meanings and ideas; therefore arguably, this provides HEIs with the opportunity to offer a more fluid and co-created interpretation of location.

\section{Present a more distinctive location on social media}

As prospective students progress in their decision making, HEIs can use other means of communication to present a more distinctive offering of location. In using social media which encourages interactivity, it becomes easier to facilitate the co-creation of a city of words as user generated content means that a selection of different location narratives can be conveyed. Judicious use of social media platforms and hashtags will enable more specific targeting of messages and allow the HEI to present its different target groups - eg mature students, business students, art students with a more distinct portrayal of location that can more readily resonate.

\section{Limitations and further research}

Our research has been based on an analysis of undergraduate prospectuses and a discussion with marketing decision makers at a single point in time. During the interviews, a number of marketing decision makers talked about being in a period of change; changes that concerned the way in which their HEI was communicating with prospective and existing students, and changes in the identity that the HEI was aiming to portray. We therefore suggest that a longitudinal study looking at how location is portrayed would enable a better understanding of the impact of location over time.

Whilst the content analysis considered location text within 105 prospectuses and found very similar images being portrayed, there has not been any further analysis to explore any subtle differences between types of HEIs such as campus/city universities, or Russell Group/Non Russell Group. A deeper content analysis of this nature would provide further insight into how location is portrayed by different types of UK HEI.

The use of social media is becoming an increasingly important channel of communication for HEIs and can inform choice for prospective students further along their decision making journey. Therefore extending the research to understand how location is being portrayed on social media 
platforms will allow a better understanding of whether or not HEIs are using location to present a more differentiated offering and capture the diversity offered by their towns and cities.

Most importantly, HEIs are yet to fully embrace the view from place marketing literature that location should be a fluid and collaborative offering. Therefore the development and subsequent empirical testing of a conceptual model to better inform construction of a dynamic place offer for HEIs would be welcomed. 


\section{Bibliography}

Aitken, R., \& Campelo, A. (2011). The four Rs of place branding. Journal of Marketing Management, 27(9-10), 913-933.

Angulo, F., Pergelova, A., \& Rialp, J. (2010). A market segmentation approach for higher education based on rational and emotional factors. Journal of Marketing for Higher Education, 20(1), 117.

Atkinson, P., \& Coffey, A. (2011). Analysing Documentary Realities. In D. Silverman, Qualitative Research. Issues of Theory, Method and Practice (3rd ed.). London: Sage.

Bennett, R., \& Ali-Choudhury, R. (2009). Prospective Students' Perceptions of University Brands: An Empirical Study. Journal of Marketing for Higher Education, 19(1), 85-107.

Braun, E., Kavaratsis, M., \& Zenker, S. (2013). My city - my brand: the different roles of residents in place branding. Journal of Place Management and Development, 6(1), 18-28.

Braun, V., \& Clarke, V. (2006). Using thematic analysis in psychology. Qualitative Research in Psychology, 3(2), 77-101.

Chapleo, C. (2010). What defines "successful” university brands? International Journal of Public Sector Management, 23(2), 169-183.

Chapleo, C. (2015). Brands in Higher Education. International Studies of Management and Organization, 45(2), 150-163.

Colomb, C., \& Kalandides, A. (2010). The 'be Berlin' campaign: Old wine in new bottles or innovative form of participatory place branding. In G. J. Ashworth, \& M. Kavaratsis, Towards Effective Place Brand Management: Branding European Cities and Regions (pp. 173-190). Cheltenham, UK/Northampton, MA: Edward Elgar.

Cresswell, T., \& Hoskins, G. (2008). Place, Persistence, and Practice: Evaluating Historical Significance at Angel Island, San Francisco, and Maxwell Street, Chicago. Annals of the Association of American Geographers, 98(2), 392-413.

Eisenschitz, A. (2010). Neo-liberalism and the future of place marketing. Place Branding and Public Diplomacy, 6(2), 79-86.

Fan, Y. (2006). Branding the nation: What is being branded? Journal of Vacation Marketing, 12(1), 514.

Hanna, S., \& Rowley, J. (2011). Towards a Strategic Place Brand-Management Model. Journal of Marketing Management, 27(5/6), 458-476. 
Hanna, S., \& Rowley, J. (2013). Place brand practitioners' perspectives on the management and evaluation of the brand experience. Town Planning Review, 84(4), 495-515.

Hanna, S., \& Rowley, J. (2015). Towards a model of the place brand web. Tourism Management, 48(June), 100-112.

Johnson, H. (2001). Neutral, colluding or subversive? Educational Management Adminstration \& Leadership, 29(3), 261-274.

Kalandides, A. (2011). The Problem with Spatial Identity: Revisiting the "Sense of Place". Journal of Place Management and Development, 4(1), 28-39.

Kaplan, M. D., Yurt, O., Gunuri, B., \& Kurtulus, K. (2010). Branding places: applying brand personality concept to cities. European Journal of Marketing, 44(9/10), 1286-1304.

Kavaratzis , M., \& Hatch, M. (2013). The dynamics of place brands: An identity-based approach to place branding theory. Marketing Theory, 13(1), 69-86.

Kemp, E., Childers, C. Y., \& Williams, K. H. (2012). Place branding: creating self-brand connections and brand advocacy. Journal of Product and Brand Management, 21(7), 508-515.

Krejcie, R. V., \& Morgan, D. W. (1970). Determining sample size for research activities. Educational and Psychological Measurements, 30, 607-610.

Lichrou, M., O'Malley, L., \& Patterson, M. (2014). On the marketing implications of place narratives. Journal of Marketing Management, 30(9-10), 832-856.

Lucarelli, A., \& Berg, P. O. (2011). City branding: a state-of-the-art review of the research domain. Journal of Place Management and Development, 4(1), 9-27.

Medway, D., \& Warnaby, G. (2014). What's in a Name? Place Branding and Toponymic Commodification. Environment and Planning A, 46(1), 153-167.

Medway, D., Swanson, K., Delpy Neirotti, L., Pasquinelli, C., \& Zenker, S. (2015). Place branding: are we wasting our time? Report of an AMA special session. Journal of Place Management and Development, 8(1), 63-68.

Miles, M. B., \& Huberman, A. M. (1994). Qualitative Data Analysis. New York: Sage .

Our Universities. (2017). Retrieved from Russell Group: http://russellgroup.ac.uk/about/ouruniversities/

Rutter, R., Lettice, F., \& Nadeau, J. (2016). Brand personality in higher education: anthropomorphised university marketing communications. Journal of Marketing for Higher Education. doi:http://dx.doi.org/10.1080/08841241.2016.1213346 
Scannell, L., \& Gifford, R. (2009). Defining place attachment: A tripartite organising framework. Journal of Environmental Psychology, 30(1), 1-10.

Shaw, J. (2013, April 17). University recruitment: one fifth of students say social media doesn't work. Retrieved from https://www.theguardian.com/higher-educationnetwork/blog/2013/apr/17/university-student-recruitment-social-media

The Russell Group. (2017). Retrieved Jan 10, 2017, from Russell Group: http://russellgroup.ac.uk/about/our-universities/

Therkelsen, A., Helkier, H., \& Jensen, O. B. (2010). Branding Aalborg: Building Community or Selling Place? In G. Ashworth, \& M. Kavaratsis, Towards Effective Place Brand Management: Branding European Cities and Regions. Cheltenham, UK/Northampton, MA: Edward Elgar.

UK Universities Marketing Forum. (2017). Retrieved from Council for Advancement and Support of Education: http://www.case.org/People_and_Communities/UK_Universities_Marketing_Forum_.html

Universities UK. (2016). University Funding Explained. London: Universities UK. Retrieved from http://www.universitiesuk.ac.uk/policy-and-analysis/reports/Documents/2016/universityfunding-explained.pdf

Veloutsou, C., Lewis, J. W., \& Paton, R. A. (2004). University selection: information requirements and importance. International Journal of Educational Management, 18(3), 160-171. doi:10.1108/09513540410527158

Warnaby, G. (2009). Towards a Service-Dominant Place Marketing Logic. Marketing Theory, 9(4), 403-423.

Warnaby, G., \& Medway, D. (2010). Semiotics and Place Branding: The Influence of the Built and Natural Environment in City Logos. In G. Ashworth, \& M. Kavaratsis, Towards Effective Place Brand Management: Branding European Cities and Regions (pp. 205-210). Cheltenham UK/Northampton MA: Edward Elgar.

Warnaby, G., \& Medway, D. (2013). What about 'place' in place marketing? Marketing Theory, 13(3), 345-363.

Winter, E., \& Chapleo, C. (2017). An exploration of the effect of servicescape on student institution choice in UK universities. Journal of Further and Higher Education, 41(2), 187-200. doi:http://dx.doi.org/10.1080/0309877X.2015.1070400 